\title{
Applicability of Databases in the Real Estate Valuation Process in the Conditions of the Emerging Economy of the Republic of Moldova
}

\author{
Svetlana Albu, Ion Albu \\ Engineering, Law and Real Estate Valuation, Technical University of Moldova, Chisinau, Republic of Moldova \\ Email: svetlana.albu@emi.utm.md
}

How to cite this paper: Albu, S. and Albu, I. (2021) Applicability of Databases in the Real Estate Valuation Process in the Conditions of the Emerging Economy of the Republic of Moldova. Open Journal of Applied Sciences, 11, 623-632.

https://doi.org/10.4236/ojapps.2021.116045

Received: May 5, 2021

Accepted: June 12, 2021

Published: June 15, 2021

Copyright (c) 2021 by author(s) and Scientific Research Publishing Inc. This work is licensed under the Creative Commons Attribution International License (CC BY 4.0).

http://creativecommons.org/licenses/by/4.0/

\begin{abstract}
The real estate valuation activity in the Republic of Moldova dates from 2002, with the adoption of Law No. 989 on Evaluation Activity. Nevertheless, the legislative and methodological framework is extremely limited. There are no national professional standards. Meanwhile, the situations that require real estate valuation are multiplying and diversifying. Therefore, the valuers apply the provisions of the International Valuation Standards (IVS) and of the European Valuation Standards (TEGoVA) adapting them to the national realities by virtue of their knowledge and experience. Information stored in databases plays an important role in the real estate valuation process. In this paper, the authors analyse the content of existing databases in the Republic of Moldova (the databases of normative documents, the information system for the cadastre of real estate, the statistical databases, and specialized databases), the quality of the included information, as well as the applicability of that information in the real estate valuation process. The disadvantages, limitations and shortcomings of databases are highlighted, and measures are proposed to increase their usefulness.
\end{abstract}

\section{Keywords}

Cadastre, Information, Statistics, Macroeconomic and Microeconomic Indices, Valuation, Databases

\section{Need for Evaluation}

The real estate valuation activity in the Republic of Moldova was formalized in 2002, with the adoption of Law No. 989 on Evaluation Activity [1]. The valuation may be voluntary or mandatory. The mandatory valuation is carried out at 
the initiative of the central and local public administration authorities, as well as regardless of the type of property ownership in the following cases:

- privatization or other ways of alienating the objects of valuation (seizure, including in the event of insolvency of the owner of the object, etc.);

- transfer of the right of use of objects in the public property of the state or leasing of these objects;

- transfer of the objects of valuation in fiduciary administration;

- expropriation for the cause of public utility of the objects of valuation;

- taxation of property and forced collection of taxes;

- reorganization and liquidation of state and municipal enterprises, and insolvent enterprises, regardless of the type of property ownership;

- the appearance of the patrimonial litigation in connection with the decision of the court, at the request of the court, including in the case of the examination of the cases concerning the amount of damage caused to the owners as a result of unlawful actions and unfair competition;

- pledging objects that are in public ownership of the state or administrativeterritorial units;

- the transmission of the objects of valuation as a contribution to the share capital of the enterprises;

- the use of intellectual property objects financed from budgetary resources and introduced in the economic circuit by economic agents, regardless of their ownership type;

- the introduction into the economic circuit of intellectual property objects by enterprises predominantly in-state property;

- the request of the administrative body carrying out the registration of the legal person.

The law also provides for the possibility of occurrence of other situations to be legislated. Evidently, the valuation can also be voluntary at the initiative of the beneficiary. The highest share of requests for voluntary valuations is for the valuations in order to guarantee loans (including for the insurance of the mortgaged/pledged assets), followed by consultations for negotiation of sale-purchase contracts, investment consultations, etc.

Over the last two decades, valuation activity has undergone multiple international changes and almost nothing nationally. The International Valuation Standards [2] after the 2000 edition, which was considered for elaboration of national normative acts, were modified and updated 7 times (in 2003, 2005, 2007, 2011, 2013, 2017, 2020 editions).

\section{Shortcomings of the Legal Framework}

In the Republic of Moldova, the legal framework of the evaluation activity was created in the period 2001-2003 by adopting the Basic Law [1], two Government Decisions No. 958 on the Approval of the Provisional Regulation on the Valuation of Real Estate [3] and No. 783 on the Evaluation of Intellectual Property 
Objects [4], and the National Securities Commission Decisions No. 36/9 on the Approval of the Regulation on Activities for Securities Valuation and Assets Relating to Them [5]. The only changes were in 2015 and only for the valuation methodology of securities valuation [6].

The existence of a rudimentary methodological framework generates erroneous interpretations by specialists and misunderstanding of the created situations. For example, in 2019 there was a requirement to estimate market rent for publicly owned land, but the normative-methodological framework of the valuation did not include the definition of "market rent" as a type of value (Table 1), and the methodology of its estimation was lacking.

Therefore, the valuers from the Republic of Moldova apply the provisions of the International Valuation Standards (IVS) and the European Standards (TEGoVA) (Table 2) adapting them to the national realities by virtue of their knowledge and experience.

Another eloquent example is the situation created at the beginning of 2021, since when banking institutions have started to request from valuers the exclusion of value-added tax (VAT) from the reported values. However, current methodologies do not indicate how to exclude VAT. The real estate market in the Republic of Moldova is not transparent, there is no information on transactions and valuers focus on supply prices or often apply indirect methods of estimating value. These situations generate additional tension between valuers and banking institutions.

\section{Databases Used in Real Estate Valuation}

Currently in the Republic of Moldova there is no methodological framework for assessing the value according to the purpose of the valuation. The particularities of real estate valuation for guaranteeing loans, financial reporting, insurance, etc. are not specified.

These shortcomings and limitations are partially compensated by the existing databases. The main databases used by valuers are:

1) The databases of normative documents (the portal of normative documents in constructions) http://www.ednc.gov.md/ [18];

2) Software packages WinSmeta and WinDox for calculating construction estimates;

3) The information system for the cadastre of real estate e-Cadastre [19] http://asp.gov.md/en/bunuri-imobile includes the legal, technical and economic aspects of the registered real estate;

4) The statistical databases provided by the National Bureau of Statistics (NBS) [20] https://statbank.statistica.md/PxWeb/pxweb/en/ and the National Bank of Moldova(NBM) [21] https://www.bnm.md/bdi/?lang=ro;

5) The private databases containing offers of real estate on the market (e.g., general platforms [22] [23] [24] and specialized databases of real estate companies [25] [26]). 
Table 1. Types of values mentioned in the legislative acts and methodological norms of the Republic of Moldova.

\begin{tabular}{|c|c|c|c|}
\hline The legal act & & Types of Value & \\
\hline Civil Code of the RM & Value of use & Market value & Replacement value \\
\hline Fiscal Code of the RM & Estimated value & Book value & \\
\hline Law on Evaluation Activity & Estimated value & Market value & \\
\hline $\begin{array}{l}\text { Provisional Regulation on the Valuation } \\
\text { of Real Estate }\end{array}$ & $\begin{array}{l}\text { Market value } \\
\text { Market value for current use }\end{array}$ & $\begin{array}{l}\text { Replacement value } \\
\text { Reproduction cost }\end{array}$ & $\begin{array}{l}\text { Investment value } \\
\text { Liquidation value (or } \\
\text { forced sale value) }\end{array}$ \\
\hline $\begin{array}{l}\text { Government Decision on the Evaluation } \\
\text { of Intellectual Property Objects }\end{array}$ & $\begin{array}{l}\text { Amortisation value } \\
\text { Insurance value } \\
\text { Balance sheet value } \\
\text { Investment value } \\
\text { Objective value }\end{array}$ & $\begin{array}{l}\text { Initial value } \\
\text { Venal value } \\
\text { (market value) } \\
\text { Liquidation value } \\
\text { Taxable value } \\
\text { Use value }\end{array}$ & $\begin{array}{l}\text { Marketable value } \\
\text { Net marketable value } \\
\text { Current value } \\
\text { (discounted) } \\
\text { Revalued amount }\end{array}$ \\
\hline
\end{tabular}

Government Decision No.1056 of 12.11 .1997

Annex No.6. Methodological indications regarding the determination of the estimated value of the patrimonial complex of the Assessed value Total balance Reproduction cost sheet value

Market value enterprise and the establishment of the sale price of the state patrimony

National Securities Commission Decisions No. 36/9 of 27.12.2001, Regulation on Activities for Securities Valuation and Assets Relating to Them

Estimated value the basic premises and assumptions in establishing the value

National Securities Commission Decisions No. $5 / 14$ of 31.01 .2015 on the approval of the Regulation on the calculation of net assets (equity) Fair value and net asset value per unit of undertakings for collective investment in transferable securities

valuation methods in accordance with the IVS (according to the fair value principle)

Law on the administration and denationalization of public property No. 121-XVI of 04.05 .2007

Law No. 488 of 08.07 .1999 on expropriation for public purpose

Compensation

Customs Service. Order no. 04-O of 04.01.2017

Methodological recommendations on the expertise and evaluation of goods Price (value) Market price Estimated price and means of transport

Law No.1308-XII of 25.07.1997 on normative price and procedure of sale and purchase of land
Market price
A specific feature of the Republic of Moldova is the use of regulations developed in the 70s of last century in the Soviet Union, which are still applied in the Commonwealth of Independent States (CIS). We refer to the Collections of the Combined Indices of the reproduction cost of all types of buildings, constructions, edifices existing in that period. There are 50 anthologies, which were digitized in order to simplify their use, and were transformed into an extremely important database for the valuation of the buildings built before 2000 [27]. 
Table 2. Valuation basis according to international and European valuation standards.

\begin{tabular}{|c|c|}
\hline International Valuation Standards (2017) & $\begin{array}{l}\text { European Valuation Standards (2020) } \\
\text { European Business Valuation Standards }\end{array}$ \\
\hline $\begin{array}{l}\text { IVS-Defined Basis of Value } \\
\text { - } \quad \text { Market Value } \\
\text { - } \quad \text { Equitket Rent } \\
\text { - } \quad \text { Investment Value/Worth } \\
\text { - } \quad \text { Synergistic Value } \\
\text { Other Basis of Value } \\
\text { - } \quad \text { Fair Value (International Financial Reporting Standards) } \\
\text { - } \quad \text { Fair Market Value (Organisation for Economic Co-operation and } \\
\text { - } \quad \text { Fair Markel Value (United States Internal Revenue Service) } \\
\text { - } \quad \text { Fair Value (Legal/Statutory) in different jurisdictions } \\
\text { Premise of Value/Assumed Use } \\
\text { - } \quad \text { Highest and Best Use } \\
\text { - Current Use/Existing Use } \\
\text { - } \quad \text { Frderly Liquidation } \\
\text { Forced Sale }\end{array}$ & $\begin{array}{l}\text { European Valuation Standards } \\
\text { - Market value } \\
\text { Other valuation bases } \\
\text { - } \quad \text { Fair value } \\
\text { - Special value } \\
\text { - Investment value } \\
\text { - } \quad \text { Mortgage lending value } \\
\text { - Insurable value } \\
\text { - Value for local and national taxation purposes } \\
\text { - } \quad \text { Value for compulsory purchase and/or compensation } \\
\text { Business Valuation Standards (2020) } \\
\text { - Market value } \\
\text { Other valuation bases } \\
\text { - } \quad \text { Fair value for financial reporting } \\
\text { - Investment value } \\
\text { - Liquidation value } \\
\text { - Liquidation value on an orderly sale basis }\end{array}$ \\
\hline
\end{tabular}

Source: [2] [16] [17].

The applicability and usefulness of information provided by the existing databases in the framework of valuation approaches and methods is further examined in this article.

Thus, the information from the first two databases is applied within the Cost Approach to estimate the value of the construction considered new by the resource method. Those databases are completed and updated every six months. Problems arise in the case of valuating atypical and specialized constructions/ buildings, or those built according to new technologies, with the application of new construction materials. Moreover, it is problematic the valuation of historic buildings, because the existing regulations do not reflect objective reality. Updating the norms for construction estimates is cumbersome, it requires financial resources for development and involves a long approval procedure.

The e-Cadastre database includes the Real Estate Register, which covers [28]: land; buildings and other capital constructions, whether they are separate real estate or component parts of the land; apartments, other detached parts of the building and parking spaces in the building, including condominium units, together with the corresponding share of ownership or surface right on the land and common parts of the building; subsoil portions. By subsoil portions as object of registration in the Real Estate Register is meant an area of land with or without constructions intended for the use of open rocks or underground space with or without constructions intended for exploitation, in both cases their existence is confirmed documentary, by the mining perimeter; plantations caught by roots. By plantations caught by roots as the object of registration in the Real Estate Register is meant perennial plantations, established in accordance with the rules defined by legislation. 
The register for each sector of land and other real estate contains chapters: A, $\mathrm{B}$ and $\mathrm{C}$. Chapters $\mathrm{A}$ and $\mathrm{B}$ are held together and contain documents on land, buildings, other real estate located on that plot of land. Chapter $\mathrm{C}$ contains documents on detached parts of the building, and it is opened if the ownership of the building and detached parts of the building are held by different persons. There are as many Chapters $\mathrm{C}$ as detached parts (apartments) registered in the given building. Chapter $\mathrm{C}$ containing information on parking spaces in the building is opened according to the same rules.

Each of the indicated chapters consists of three subchapters: I, II and III. The real estate is registered in subchapter I of each chapter. The property rights are recorded in subchapter II of each chapter of the Register. Other real rights and encumbrances are recorded in subchapter III of each chapter of the Register. Subchapter III consists further of two parts: part 1 contains entries regarding other rights subject to registration (surface right, usufruct rights, use, habitation rights, servitude, mortgages, right of use of land of state or administrative-territorial units, concession, the right of administration, economic management); part 2 contains entries regarding the rights of claim, legal facts or relations related to real estate.

In addition, the database also contains information on the value of real estate for taxation purposes. This kind of valuation in the Republic of Moldova is carried out centrally at the state level through the methods of mass valuation. The technical characteristics included in this tab depend on the type of real estate, for example the apartment is described in detail: the use; cadastral number; address; the area according to the legal document; total area; balcony/terrace area; floor number; number of rooms; location at the corner; gas; heating; water; sewerage; bathroom; WC.

The shortcomings of the Cadastre database are: the data are incomplete (not all objects are registered) and some erroneous information is included (outdated information, borders, inaccurate area). The problem of the section "Estimation of real estate for tax purposes" is the outdated information (the last valuation of residential real estate took place on 01.06.2004).

Statistical databases (NBS and NBM) provide information applied, in particular, in the cost and income approaches. The NBS quarterly estimates the price indices in construction as well as the price indices for construction-assembly works in constant 1991 prices [29].

The NBM provides information on exchange rates. This information is extremely important in the valuation process because all offers on the real estate market (with very few exceptions) indicate prices in euros, and transactions can only be concluded in national currency.

The NBM database also provides the information applied for estimating discount and capitalization rates (within the income approach), for estimating functional and economic depreciation (within the cost approach): annual inflation rate, interest rates (including base rate), and from 2020 the residential property 
price index [30] (calculated on the basis of published offers and not on the basis of actual transactions).

International practice recommends estimating the market value of real estate on the basis of comparative analysis of transactions. In the Republic of Moldova there is no access to information on transactions, therefore the reality corrects the essence of the method in the comparative analysis of offers.

Databases of real estate are created and monitored by real estate agencies and private persons these are general information platforms on real estate offers (for example: [22] [23] [24] [25] [26]). The shortcomings of these databases consist of limited, incomplete information on the property, dissemination of erroneous information (it is not required to verify this information). However, the valuers use the available information and draw their own conclusions based on it.

The basic approach in the real estate valuation process is the market approach. However, in the Republic of Moldova the market exists only in municipalities and district centers. Thus, the cost approach becomes very important in the context of lack or a limited market. In order to estimate the value of the construction within the cost approach, the legislation indicates the application of the unit comparison method based on the combined indices of reproduction cost (CIRC). The electronic version of the CIRC is an extensive database of 50 anthologies for the revaluation and estimation of physical wear of all types of buildings and constructions existing in the USSR until 1970 [31].

The reproduction cost per reference unit $(\mathrm{m} 3, \mathrm{~m} 2, \mathrm{LM}$, etc.) is indicated according to the branch of industry, mode of use, technical characteristics (foundation material, load-bearing and partition walls, floor, floor coverings, roof, existing engineering networks, etc.). Corrections are also recommended in case of deviation of the object of valuation from the standard and distribution of the reproduction cost on the construction elements. This database only exists in Russian language. In 1997, the updated version of the extract from CIRC was approved in the Republic of Moldova under the name "Collection of combined indices of the inventory value (CIIV) of real estate for the calculation of the state tax when performing transactions such as purchase, sale, exchange, donation, pledge, inheritance" [32].

Currently, the application of the CIRC and CIIV is justified only for the objects built until 2000. The constructions of the last two decades do not fall within the norms considered in the development of the CIRC. Therefore, the unit comparison method cannot be applied to new constructions.

According to the legislation of the Republic of Moldova, the elaboration of the construction estimates is mandatory only for the objects financed from public funds. Since, for privately funded objects the elaboration of the construction estimates is of recommendation nature, in practice, it is not elaborated, using the direct negotiation of the final amount. Thus, in the valuation process neither the resource method can be applied, nor its derivatives the resource and index method and the basic index method. 
As the information required for the application of the methods specified in the Provisional Regulation [3] does not exist, the application of the cost approach becomes problematic for constructions built after 2000 .

\section{Conclusions: Solutions to Increase the Usefulness of Databases for Real Estate Valuation}

The analysis of the information contained in the existing databases and applied in the process of real estate valuation in the Republic of Moldova revealed huge gaps that prevent the correct assessment of the value.

In order to increase the usefulness of existing information applied by valuers in the cost approach, it is recommended:

- to update the norms for construction estimates (normative time for the performance of works, consumption of materials, type of materials used, technology applied, current prices), including for the rehabilitation and restoration of historic buildings;

- to indicate in the legislation the mandatory elaboration of the budget estimates by the method of resources for the construction works regardless of the source of financing, this will also protect the consumer and avoid existing frauds;

- to report the generalized information on the construction and the total estimated cost to the NBS, and based on the accumulated information to determine updated combined indices for the objects built in the 21st century.

In order to increase the usefulness of existing information applied by valuers in the market approach, it is recommended:

- to require the mandatory registration of real estate transactions within a short time after the transaction is completed (for example 10 days);

- to create a transaction database within the Cadastre Department of the Public Services Agency (PSA). The PSA already has all the information on the transactions, and it has to be digitized. It should be admitted that prices indicated in the contracts do not always reflect reality, although the trend of recent years confirms that more and more people understand the need to indicate the real price (especially in the case of mortgage).

\section{Acknowledgements}

The research was carried out within the project 20.80009.0807.34 increasing the value of architectural heritage of the Republic of Moldova.

\section{Conflicts of Interest}

The authors declare no conflicts of interest regarding the publication of this paper.

\section{References}

[1] Law on Evaluation Activity No. 989-XV of 18.04.2002. In: Official Gazette No. 102 
of 16.07.2002.

http://lex.justice.md/viewdoc.php?action=view\&view=doc\&id=312892\&lang=1

[2] International Valuation Standards.

https://www.ivsc.org/standards/international-valuation-standards/IVS

[3] Government Decision No. 958 of 04.08.2003 on the Approval of the Provisional Regulation on the Valuation of Real Estate. In: Official Gazette No. 177 of 15.08.2003. http://lex.justice.md/viewdoc.php?action=view\&view=doc\&id=305725\&lang=1

[4] Government Decision No. 783 of 30.06 .2003 on the Evaluation of Intellectual Property Objects. https://www.legis.md/cautare/getResults?doc_id=95768\&lang=ro

[5] National Securities Commission Decisions No. 36/9 of 27.12.2001 on the Approval of the Regulation on Activities for Securities Valuation and Assets Relating to Them. https://www.legis.md/cautare/getResults?doc_id=80016\&lang=ro

[6] National Securities Commission Decisions No. 5/14 of 31.01.2015 on the Approval of the Regulation on the Calculation of Net Assets (Equity) and Net Asset Value per Unit of Undertakings for Collective Investment in Transferable Securities. In: Official Gazette No. 78-83/592 of 03.04.2015.

https://cancelaria.gov.md/sites/default/files/hot_5_14.pdf

[7] Civil Code of the Republic of Moldova No. 1107-XV of 06.06.2002. https://www.legis.md/cautare/getResults?doc_id=112573\&lang=ro

[8] Tax Code No. 1163-XIII of 24.04.97. https://sfs.md/en/page/tax-code

[9] Law on the Administration and Denationalization of Public Property No. 121-XVI of 04.05.2007. https://www.legis.md/cautare/getResults?doc_id=115473\&lang=ro

[10] Law on Real Estate Formation No. 354-XV of 28.10.2004. https://www.legis.md/cautare/getResults?doc_id=16004\&lang=ru

[11] Law No. 488 of 08.07.1999 on Expropriation for Public Purpose. https://www.legis.md/cautare/getResults?doc_id=108345\&lang=ro

[12] Law No. 68 of 14.04.2016 on the Judicial Expertise and the Status of the Judicial Expert. https://www.legis.md/cautare/getResults?doc_id=93158\&lang=ro

[13] Law No.1308-XII of 25.07.1997 on Normative Price and Procedure of Sale and Purchase of Land. https://www.legis.md/cautare/getResults?doc_id=18973\&lang=ro

[14] Government Decision No. 1056 of 12.11 .1997 on the Measures for the Implementation of the Law on the Privatization Program for the Years 1997-1998. Annex No. 6. Methodological Indications Regarding the Determination of the Estimated Value of the Patrimonial Complex of the Enterprise and the Establishment of the Sale Price of the State Patrimony. https://www.legis.md/cautare/getResults?doc_id=87588\&lang=ro

[15] Ministry of Finance of the Republic of Moldova, Customs Service. Order No. 04-O of 04.01.2017 Methodological Recommendations on the Expertise and Evaluation of Goods and Means of Transport.

https://customs.gov.md/ro/articles/laboratorul-vamal

[16] European Valuation Standards 2020. Ninth Edition ISBN 9789081906050. TEGOVA. https://www.tegova.org/en/p5fa0280f9d296

[17] European Business Valuation Standards 2020. First Edition. ISBN 9789081906043. TEGOVA. https://www.tegova.org/en/p5eb28f75f2df4

[18] eDNC. Normative Documents in Construction. http://www.ednc.gov.md

[19] The Information System for the Cadastre of Real Estate e-Cadastre. PE "Public Services Agency". http://asp.gov.md/en/bunuri-imobile 
[20] Statistical Databank. National Bureau of Statistics. https://statbank.statistica.md/PxWeb/pxweb/en

[21] Interactive Database. National Bank of Moldova. https://www.bnm.md/bdi/pages/mainPage.xhtml

[22] https://999.md/ro/category/real-estate

[23] https://makler.md/md/real-estate

[24] http://900.md/view.php?razid=05

[25] Real Estate Agency Lara. http://lara.md/en/apartments/prodazha_kvartir?lang=en

[26] Real Estate Agency Proimobil. https://proimobil.md

[27] Collections of Enlarged Indicators of the Replacement Cost of Buildings and Structures. УПВС-Сборники укрупненных показателей восстановительной стоимости зданий и сооружений. https://upvs-online.ru

[28] The Instruction on the Registration of Real Estate and Rights over Them, Approved by the Order of Agency for Land Relations and Cadastre No. 112 of 22.06.2005. https://www.legis.md/cautare/getResults?doc_id=115484\&lang=ro

[29] Price Indices for Construction-Assembly Works. https://statbank.statistica.md/PxWeb/pxweb/en/40\%20Statistica\%20economica/40 \%20Statistica\%20economica_05\%20PRE_PRE040/PRE040300.px/?rxid=8e69070f -3ac5-4b22-ab66-eab8ee8cc25a

[30] Residential Property Price Index. https://www.bnm.md/ro/content/indicele-pretului-bunurilor-imobile-rezidentiale-r ppi-trimestrul-iv-2020

[31] One-Level Brick Residential Buildings. https://upvs-online.ru/upvs-sborniki-ukrupnennyh-pokazatel/sbornik-26-zdanija-isooruzheni-

ja-v-sovhozah-kolhozah-mezhkolhoznyh-i-drugih-selskohozjajstvennyh-predprijati jah-i-organizacijah/tom-ii-zhilye-kulturno-bytovye-i-administrativno-hozjajstvenn ye-zdanija/otdel-i-zhilye-doma/tablica-1-zhilye-doma-odnojetazhnye-kirpichnye

[32] Collection of Combined Indices of the Inventory Value of Real Estate for the Calculation of the State Tax When Performing Transactions Such as Purchase, Sale, Exchange, Donation, Pledge, Inheritance. Approved by Ministry of Finance on 15.06.1997. In: Official Gazette No. 43-44/68 of 03.07.1997.

https://www.legis.md/cautare/getResults?doc_id=81881\&lang=ro. 